\title{
Aligning Articles in TV Newscasts and Newspapers
}

\author{
Yasuhiko Watanabe Yoshihiro Okada \\ Kengo kaneji \\ Makoto Nagao \\ Ryukoku University \\ Ryukoku Univ. \\ Ryukoku Univ. \\ Seta, Otsu \\ Shiga, Japan \\ Seta, Otsu \\ Seta, Otsu \\ Shiga, Japan \\ Shiga, Japan \\ Kyoto University \\ Yoshida, Sakyo-ku \\ Kyoto, Japan \\ watanabe@rins.ryukoku.ac.jp
}

\begin{abstract}
It is important to use pattern information (e.g. TV newscasts) and textual information (e.g. newspapers) together. For this purpose, we describe a method for aligning articles in TV newscasts and newspapers. In order to align articles, the alignment system uses words extracted from telops in TV newscasts. The recall and the precision of the alignment process are $97 \%$ and $89 \%$, respectively. In addition, using the results of the alignment process, we develop a browsing and retrieval system for articles in TV newscasts and newspapers.
\end{abstract}

\section{Introduction}

Pattern information and natural language information used together can complement and reinforce each other to enable more effective communication than can either medium alone (Feiner 91) (Nakamura 93). One of the good examples is a TV newscast and a newspaper. In a TV newscast, events are reported clearly and intuitively with speech and image information. On the other hand, in a newspaper, the same events are reported by text information more precisely than in the corresponding TV newscast. Figure 1 and Figure 2 are examples of articles in TV newscasts and newspapers, respectively, and report the same accident, that is, the airplane crash in which the Commerce Secretary was killed. However, it is difficult to use newspapers and TV newscasts together without aligning articles in the newspapers with those in the TV newscasts. In this paper, we propose a method for aligning articles in newspapers and TV newscasts. In addition, we show a browsing and retrieval system for aligned articles in newspapers and TV newscasts.

\section{TV Newscasts and Newspapers}

\subsection{TV Newscasts}

In a TV newscast, events are generally reported in the following modalities:

- image information,

- speech information, and
- text information (telops).

In TV newscasts, the image and the speech information are main modalities. However, it is diffcult to obtain the precise information from these kinds of modalities. The text information, on the other hand, is a secondary modality in TV newscasts, which gives us:

- explanations of image information,

- summaries of speech information, and

- information which is not concerned with the reports (e.g. a time signal).

In these three types of information, the first and second ones represent the contents of the reports. Moreover, it is not difficult to extract text information from TV newscasts. It is because a lots of works has been done on character recognition and layout analysis (Sakai 93) (Mino 96) (Sato 98). Consequently, we use this textual information for aligning the TV newscasts with the corresponding newspaper articles. The method for extracting the textual information is discussed in Section 3.1. But, we do not treat the method of character recognition in detail, because it is beyond the main subject of this study.

\subsection{Newspapers}

A text in a newspaper article may be divided into four parts:

- headline,

- explanation of pictures,

- first paragraph, and

- the rest.

In a text of a newspaper article, several kinds of information are generally given in important order. In other words, a headline and a first paragraph in a newspaper article give us the most important information. In contrast to this, the rest in a newspaper article give us the additional information. Consequently, headlines and first paragraphs contain more significant words (keywords) for representing the contents of the article than the rest. 

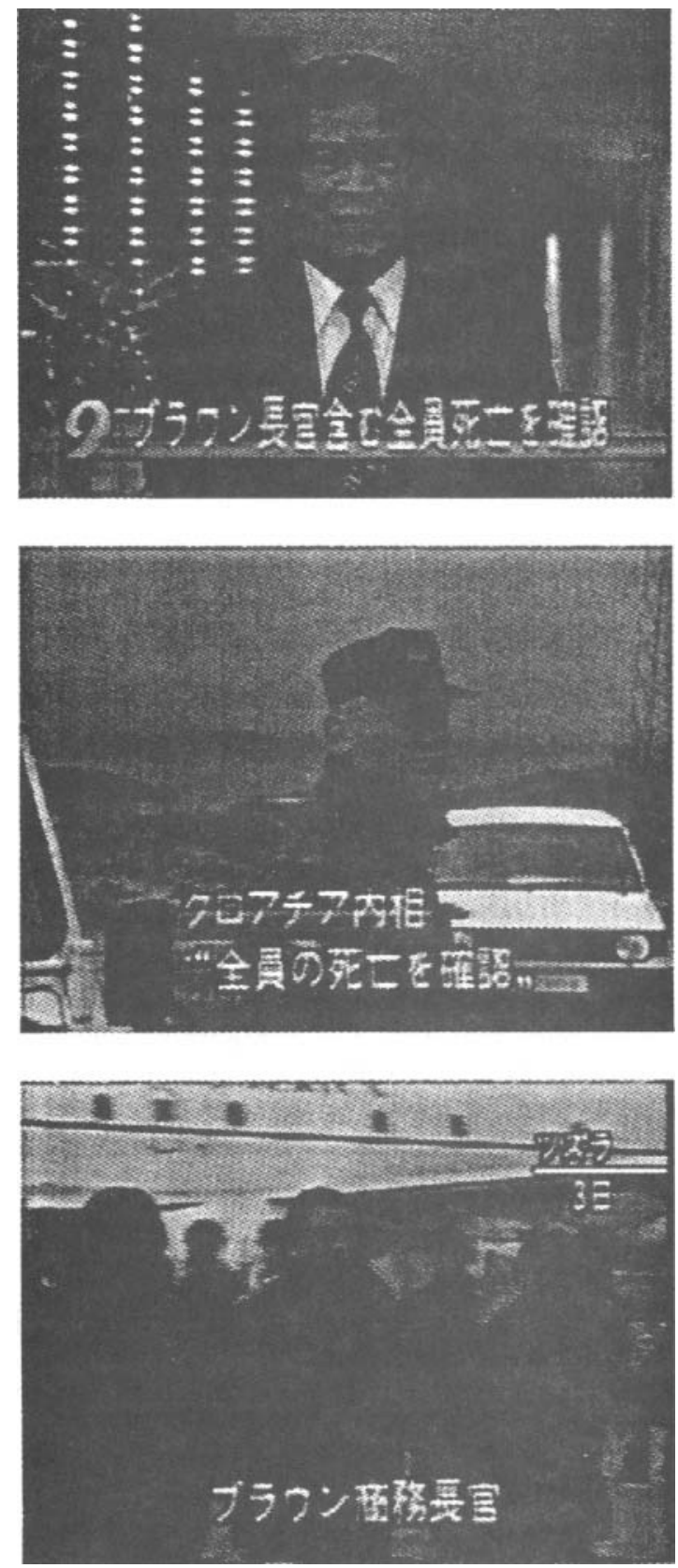

Figure 1: An example of TV news articles (NHK evening TV newscasts; April, 4, 1996)

On the other hand, an explanation of a picture in an article shows us persons and things in the picture that are concerned with the report. For example, in Figure 2, texts in bold letters under the picture is an explanation of the picture. Consequently, explanations of pictures contain many keywords as well as headlines and first paragraphs.

In this way, keywords in a newspaper article are distributed unevenly. In other words, keywords are more frequently in the headline, the explanation of
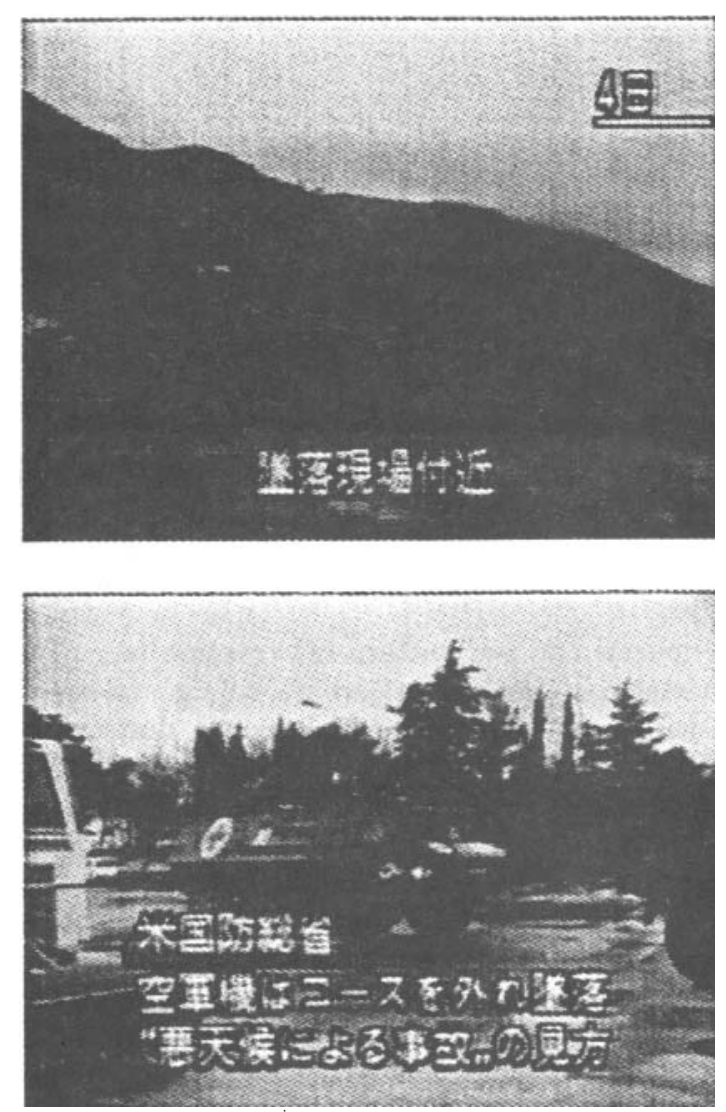

Telops in these TV news images

\begin{tabular}{ll}
\hline top left: & $\begin{array}{l}\text { All the passengers, including } \\
\text { Commerce Secy Brown, were } \\
\text { killed }\end{array}$ \\
top right: & $\begin{array}{l}\text { crush point, the forth day } \\
\text { middle left: } \\
\text { [Croatian Minister of Domes- } \\
\text { tic Affairs] "All passengers } \\
\text { were killed" }\end{array}$ \\
middle right: & $\begin{array}{l}\text { [Pentagon] The plane was off } \\
\text { course. "accident under bad } \\
\text { weather condition". } \\
\text { Commerce Secy Brown, Tu- } \\
\text { zla, the third day }\end{array}$ \\
\hline
\end{tabular}

the pictures, and the first paragraph. In addition, these keywords are shared by the newspaper article with TV newscasts. For these reasons, we align articles in TV newscasts and newspapers using the following clues:

- location of keywords in each article,

- frequency of keywords in each article, and

- length of keywords. 


\section{米商務長官ら全員の死亡確認}

クロアチア最南部のドブロブニク付近で 3 日午後、旧 ユーゴ各国を視察中のブラウン米商䅂長官ら乗員・乗客 計 33 人が乗った米空軍機が崕落した事故で、クロアチフ 政府は 4 日、ブラウン長官を含む乗客ら全員の死亡を確 認したと吉明した。等落当時、現易は強的風雨に見舞わ れてレた。国防綕省スポークスマンは、砲俥や爆弾テロ の可能性は考えられない、と述へた。

クリントン大㓍領は商務省て「「バカン半島に平和を 根付かせるため、米国の経済力の生かし方を探る視察で、 長官はたいへん意気込んでいた。長官は私にとって最も 有能なアドバイザーの 1 人だった」と語った。ブラウン 長官は今月中旬のクリントン大統領の訪日K同行する予 定だった。

今回の事故にからみ、商䅂省は、メアリー・グッド次 官（技術担当）を長官代行化任命した。

乗客は27人で、商務省職員や、旧ユーゴの復興に関心 を寄せる米企業幹部、ニニーヨーク・タイムズ紙記者ら が含まれていた。

米国人はボスニアで、和平協竓を推進した外交官 3 人 が昨年夏、事故で死亡した。今年 1 月Kは、米兵 2 人が やはり事故で死亡した。

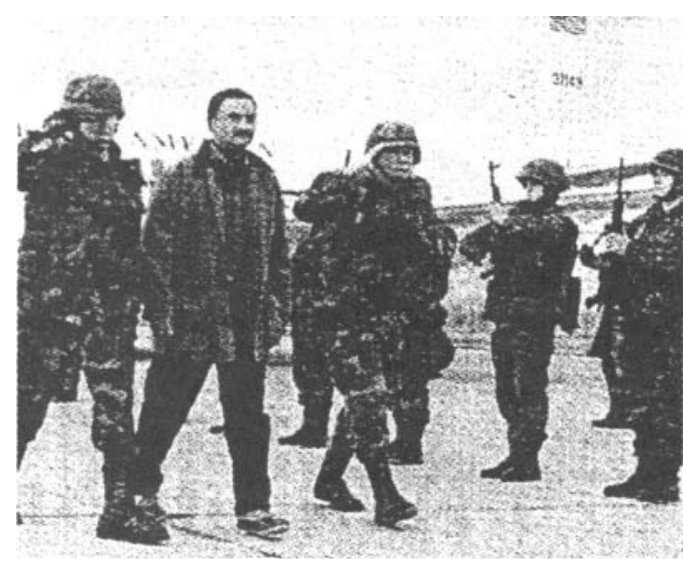

《写真》ボスニア・ヘルツェゴビナのツズラにある空軍基 地に到着、軍用のボーインタ737 型機から降りて兵士た

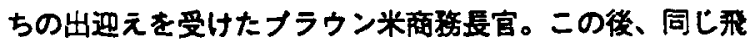
行譏に再ひ乗ってドブブニクに向かう途中に事故が起き たニロイター

Summary of this article: On Apr 4, the Croatian Government confirmed that Commerce Secretary Ronald H. Brown and 32 other people were all killed in the crash of a US Air Force plane near the Dubrovnik airport in the Balkans on Apr 3, 1996. It was raining hard near the airport at that time. A Pentagon spokesman said there are no signs of terrorist act in this crash. The passengers included members of Brown's staff, private business leaders, and a correspondent for the New York Times. President Clinton, speaking at the Commerce Department, praised Brown as 'one of the best advisers and ablest people I ever knew.' On account of this accident, Vice Secretary Mary Good was appointed to the acting Secretary. In the Balkans, three U.S. officials on a peace mission and two U.S. soldiers were killed in Aug 1995 and Jan 1996, respectively.

(Photo) Commerce Secy Brown got off a military plane Boeing 737 and met soldiers at the Tuzla airport in Bosnia. The plane crashed and killed Commerce Secy Brown when it went down to Dubrovnik.

Figure 2: An example of newspaper articles (Asahi Newspaper; April, 4, 1996)

\section{Aligning Articles in TV Newscasts and Newspapers}

\subsection{Extracting Nouns from Telops}

An article in the TV newscast generally shares many words, especially nouns, with the newspaper article which reports the same event. Making use of these nouns, we align articles in the TV newscast and in the newspaper. For this purpose, we extract nouns from the telops as follows:

Step 1 Extract texts from the TV images by hands. For example, we extract "Okinawa ken Ohta chiji" from the TV image of Figure 3. When the text is a title, we describe it. It is not difficult to find title texts because they have specific expression patterns, for example, an underline (Figure 4 and a top left picture in Figure 1). In addition, we describe the follow-

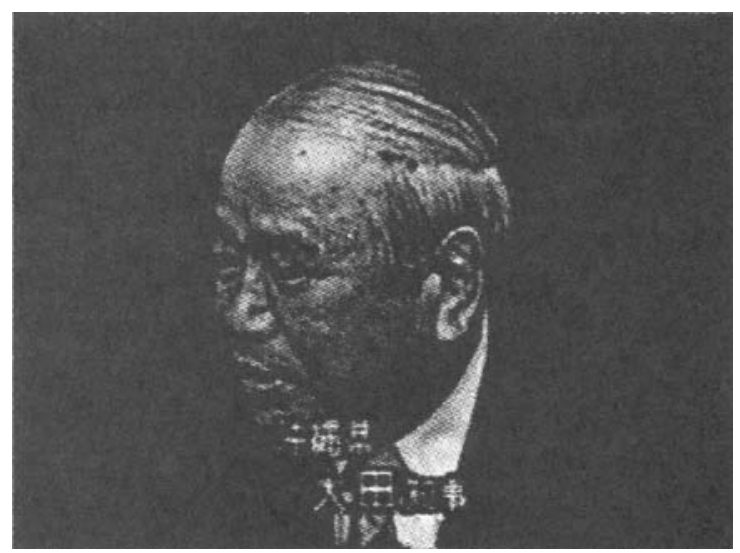

Figure 3: An example of texts in a TV newscast: "Okinawa ken Ohta chiji (Ohta, Governor of Okinawa Prefecture)" 


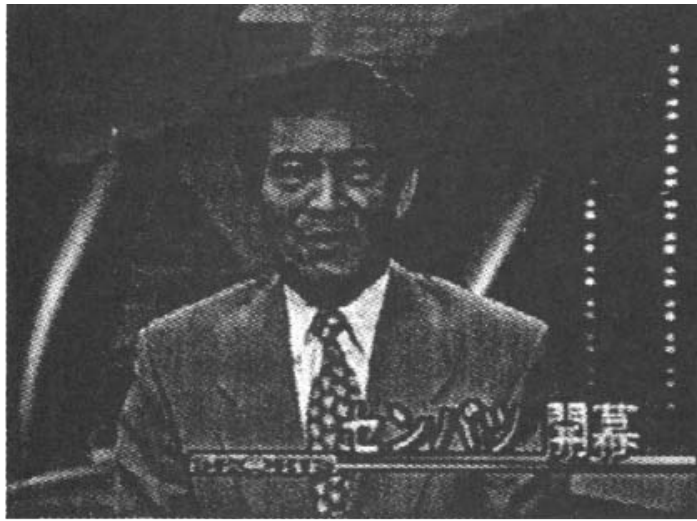

Figure 4: An example of title texts: "zantei yosanan asu shu-in tsuka he (The House of Rep. will pass the provisional budget tomorrow)"

ing kinds of information:

- size of each character

- distance between characters

- position of each telop in a TV image

Step 2 Divide the texts extracted in Step 1 into lines. Then, segment these lines at the point where the size of character or the distance between characters changes. For example, the text in Figure 3 is divided into "Okinawa ken (Okinawa Prefecture)", "Ohta (Ohta)", and "chiji (Governor)".

Step 3 Segment the texts by the morphological analyzer JUMAN (Kurohashi 97).

Step 4 Analyze telops in TV images. Figure 5 shows several kinds of information which are explained by telops in TV Newscasts (Watanabe 96). In (Watanabe 96), a method of semantic analysis of telops was proposed and the correct recognition of the method was $92 \%$. We use this method and obtain the semantic interpretation of each telop.

Step 5 Extract nouns from the following kinds of telops.

- telops which explain the contents of TV images (except "time of photographing" and "image data")

- telops which explain a fact

It is because these kinds of telops may contain adequate words for aligning articles. On the contrary, we do not extract nouns from the other kinds of telops for aligning articles. For example, we do not extract nouns from telops which are categorized into a quotation of a speech in Step 4. It is because a quotation of a speech is used as the additional infor-
1. explanation of contents of a TV image

(a) explanation of a scene

(b) explanation of an element

i. person

ii. group and organization

iii. thing

(c) bibliographic information

i. time of photographing

ii. place of photographing

iii. image data

2. quotation of a speech

3. explanation of a fact

(a) titles of TV news

(b) diagram and table

(c) other

4. information which is not concerned with a report

(a) current time

(b) broadcasting style

(c) names of an announcer and reporters

Figure 5: Information explained by telops in TV Newscasts

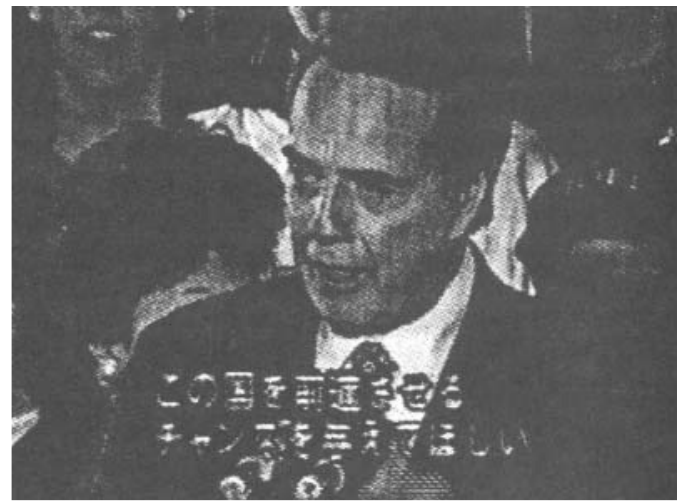

Figure 6: An example of a quotation of a speech: "kono kuni wo zenshin saseru chansu wo atae te hoshii (Give me a chance to develop our country)"

mation and may contain inadequate words for aligning articles. Figure 6 shows an example of a quotation of a speech.

\subsection{Extraction of Layout Information in Newspaper Articles}

For aligning with articles in TV newscasts, we use newspaper articles which are distributed in the Internet. The reasons are as follows: 
Table 1: The weight $w(i, j)$

\begin{tabular}{|c|c||c|c|c|c|}
\hline \multicolumn{2}{|c||}{} & \multicolumn{4}{c|}{ newspaper } \\
\cline { 2 - 7 } \multicolumn{2}{|c||}{} & title & pict. expl. & first par. & the rest \\
\hline \hline $\mathrm{T}$ & title & 8 & 4 & 4 & 2 \\
\cline { 2 - 7 } $\mathrm{V}$ & the rest & 4 & 2 & 2 & 1 \\
\hline
\end{tabular}

- articles are created in the electronic form, and

- articles are created by authors using HTML which offers embedded codes (tags) to designate headlines, paragraph breaks, and so on.

Taking advantage of the HTML tags, we divide newspaper articles into four parts:

- headline,

- explanation of pictures,

- first paragraph, and

- the rest.

The procedure for dividing a newspaper article is as follows.

1. Extract a headline using tags for headlines.

2. Divide an article into the paragraphs using tags for paragraph breaks.

3. Extract paragraphs which start “ 《写真》 (shashin, picture)" as the explanation of pictures.

4. Extract the top paragraph as the first paragraph. The others are classified into the rest.

\subsection{Procedure for Aligning Articles}

Before aligning articles in TV newscasts and newspapers, we chose corresponding TV newscasts and newspapers. For example, an evening TV newscast is aligned with the evening paper of the same day and with the morning paper of the next day. We aligned articles within these pairs of TV newscasts and newspapers.

The alignment process consists of two steps. First, we calculate reliability scores for an article in the TV newscasts with each article in the corresponding newspapers. Then, we select the newspaper article with the maximum reliability score as the corresponding one. If the maximum score is less than the given threshold, the articles are not aligned.

As mentioned earlier, we calculate the reliability scores using these kinds of clue information:

- location of words in each article,

- frequency of words in each article, and

- length of words.

If we are given a TV news article $x$ and a newspaper article $y$, we obtain the reliability score by using the

\begin{tabular}{|l||c|}
\hline the number of the articles in the TV newscasts & 143 \\
\hline the number of the corresponding article pairs & 100 \\
\hline the number of the pairs of aligned articles & 109 \\
\hline the number of the correct pairs of aligned articles & 97 \\
\hline
\end{tabular}

Figure 7: The results of the alignment

words $k(k=1 \cdots N)$ which are extracted from the TV news article $x$ :

$$
\begin{aligned}
& \operatorname{SCORE}(x, y)= \\
& \sum_{k=1}^{N} \sum_{i=1}^{4} \sum_{j=1}^{2} w(i, j) \cdot f_{\text {paper }}(i, k) \cdot f_{T V}(j, k) \cdot \text { length }(k)
\end{aligned}
$$

where $w(i, j)$ is the weight which is given to according to the location of word $k$ in each article. We fixed the values of $w(i, j)$ as shown in Table 1 . As shown in Table 1, we divided a newspaper article into four parts: (1) title, (2) explanation of pictures, (3) first paragraph, and (4) the rest. Also, we divided texts in a TV newscasts into two: (1) title, and (2) the rest. It is because keywords are distributed unevenly in articles of newspapers and TV newscasts. $f_{\text {paper }}(i, k)$ and $f_{T V}(j, k)$ are the frequencies of the word $k$ in the location $i$ of the newspaper and in the location $j$ of the TV news, respectively. length $(k)$ is the length of the word $k$.

\section{Experimental Results}

To evaluate our approach, we aligned articles in the following TV newscasts and newspapers:

- NHK evening TV newscast, and

- Asahi newspaper (distributed in the Internet). We used 143 articles of the evening TV newscasts in this experiment. As mentioned previously, articles in the evening TV newscasts were aligned with articles in the evening paper of the same day and in the morning paper of the next day. Figure 7 shows the results of the alignment. In this experiment, the threshold was set to 100 . We used two measures for evaluating the results: recall and precision. The recall and the precision are $97 \%$ and $89 \%$, respectively.

One cause of the failures is abbreviation of words. For example, "shinyo-kinko (credit association)" is abbreviated to "shinkin". In our method, these words lower the reliability scores. To solve this problem, we would like to improve the alignment performance by using dynamic programming matching method for string matching. (Tsunoda 96) has reported that the results of the alignment were improved by using dynamic programming matching method.

In this experiment, we did not align the TV news articles of sports, weather, stock prices, and foreign 


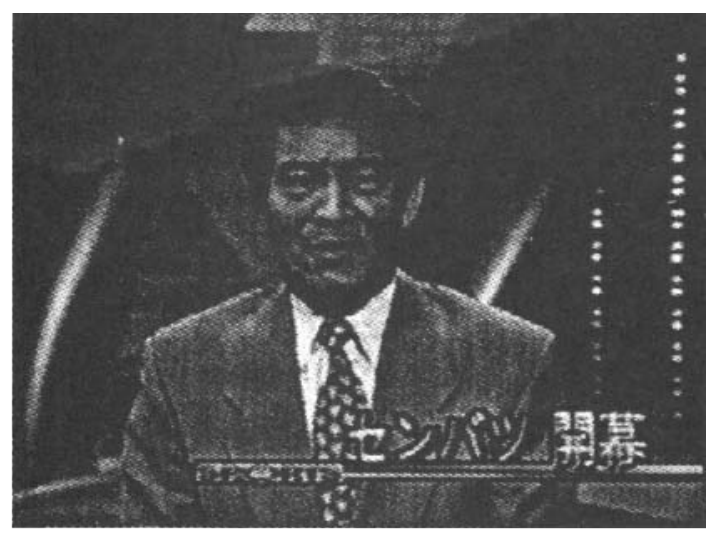

Figure 8: An example of a sports news article: "senbatsu kaimaku (Inter-high school baseball games start)"

exchange. It is because the styles of these kinds of TV news articles are fixed and quite different from those of the others. From this, we concluded that we had better align these kinds of TV news articles by the different method from ours. As a result of this, we omitted TV news articles the title text of which had the special underline for these kinds of TV news articles. For example, Figure 8 shows a special underline for a sports news.

\section{Browsing and Retrieval System for Articles in TV Newscasts and Newspapers}

The alignment process has a capability for information retrieval, that is, browsing and retrieving articles in TV newscasts and newspapers. As a result, using the results of the alignment process, we developed a browsing and retrieval system for TV newscasts and newspapers. Figure 9 shows the overview of the system. The important points for this system are as follows:

- Newspaper articles and TV news articles are cross-referenced.

- A user can consult articles in TV newscasts and newspapers by means of the dates of broadcasting or publishing.

- A user can consult newspaper articles by full text retrieval. In the same way, user can consult TV newscasts which are aligned with retrieved newspaper articles. In other words, content based retrieval for TV newscasts is available.

- Newspaper articles are written in HTML. In addition to this, the results of the alignment process are embedded in the HTML texts. As a result, we can use a WWW browser (e.g.

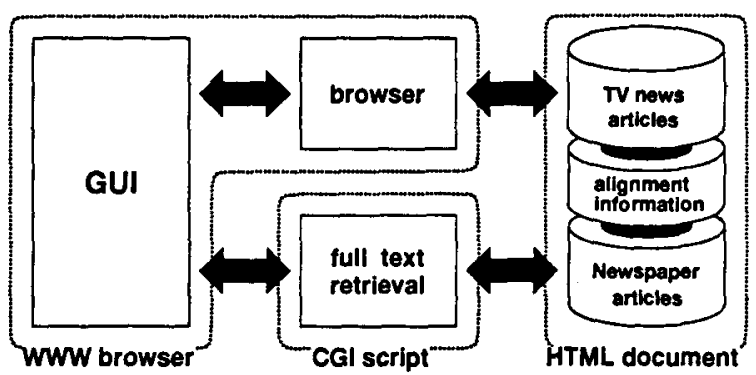

Figure 9: System overview

Netscape, Internet Explorer, etc) for browsing and retrieving articles in TV newscasts and newspapers.

A user can consult articles in newspapers and TV newscasts by full text retrieval in this way: when the user gives a query word to the system, the system shows the titles and the dates of the newspaper articles which contain the given word. At the same time, the system shows the titles of TV news articles which are linked to the retrieved newspaper articles. For example, a user obtains 13 newspaper articles and $4 \mathrm{TV}$ news articles when he gives "saishutsu (annual expenditure)" as a query word to the system. One of them, entitled "General annual expenditure dropped for three successive years" (June, 4, 1997), is shown in Figure 10. The newspaper article in Figure 10 has an icon in the above right, looks like an opening scene of a TV news article. The icons shows this article is linked to the TV news article. When the user select this icon, the system shows the TV news article "Public work costs were a seven percent decrease" (the top left window in Figure 10).

\section{References}

Feiner, McKeown: Automating the Generation of Coordinated Multimedia Explanations, IEEE Computer, Vol.24 No.10, (1991).

Nakamura, Furukawa, Nagao: Diagram Understanding Utilizing Natural Language Text, 2nd International Conference on Document Analysis and Recognition, (1993).

Kurohashi, Nagao: JUMAN Manual version 3.4 (in Japanese), Nagao Lab., Kyoto University, (1997) ${ }^{1}$.

Mino: Intelligent Retrieval for Video Media (in Japanese), Journal of Japan Society for Artificial Intelligence Vol.11 No.1, (1996).

${ }^{1}$ The source file and the explanation (in Japanese) of Japanese morphological analyzer JUMAN can be obtained using anonymous FTP from

$\mathrm{ftp}: / /$ pine.kuee.kyoto-u.ac.jp/pub/juman/juman3.4.tar.gz 


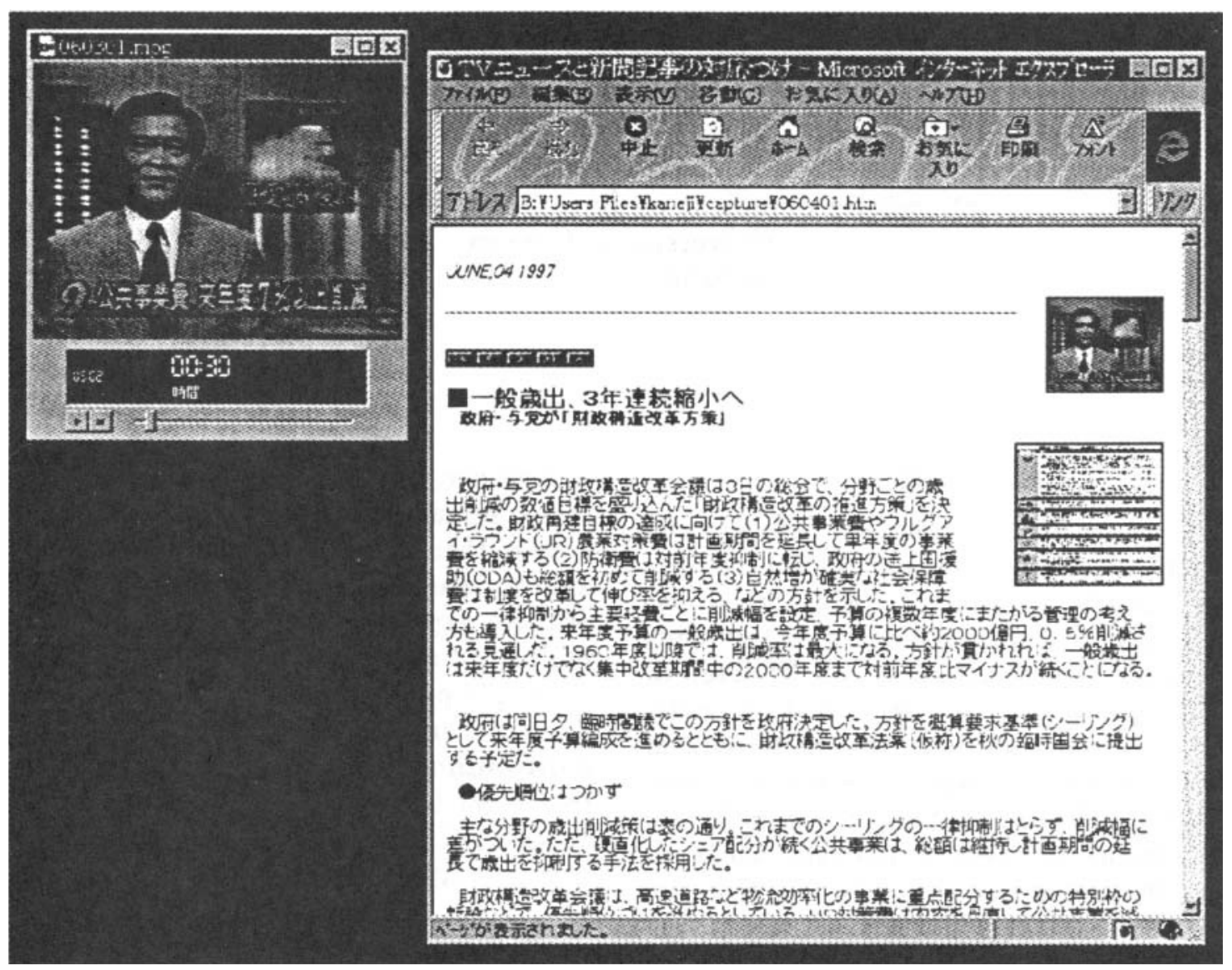

Figure 10: An output of the reference system for articles in TV newscast and newspapers: "Public work costs were a seven percent decrease" and "General annual expenditure dropped for three successive years"

Sakai: A History and Evolution of Document Information Processing, 2nd International Conference on Document Analysis and Recognition, (1993).

Sato, Hughes, and Kanade: Video OCR for Digital News Archive, IEEE International Workshop on Contentbased Access of Image and Video Databases, (1998).

Tsunoda, Ooishi, Watanabe, Nagao: Automatic Alignment between TV News and Newspaper Articles by Maximum Length String between Captions and $\mathrm{Ar}$ ticle Texts (in Japanese), IPSJ-WGNL 96-NL-115, (1996).

Watanabe, Okada, Nagao: Semantic Analysis of Telops in TV Newscasts (in Japanese). IPSJ-WGNL 96NL-116, (1996). 